MAKALAH

\title{
MODERNISASI DI BERBAGAI ASPEK
}

Diajukan untuk memenuuhi tugas Mata Kuliah Sejarah Eropa

(Kode 872010001420)

Dosen Pengampu :

Dr. Mohamad Zaenal Arifin Anis, M.Hum

Mansyur, S.Pd., M.Hum

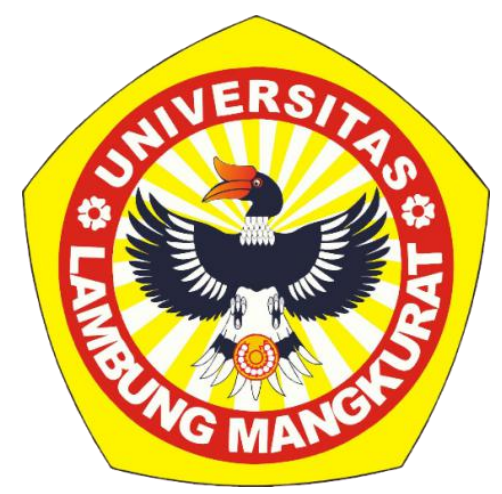

Disusun Oleh :

\section{Kelompok 7}

$\begin{array}{ll}\text { Alliya Rahmatika } & 2010111120015 \\ \text { Farah Mu'thia } & 2010111220022 \\ \text { Nellyana Azizah } & 2010111220014\end{array}$

A1 Sejarah

PROGRAM STUDI PENDIDIKAN SEJARAH

JURUSAN PENDIDIKAN ILMU PENGETAHUAN SOSIAL

FAKULTAS KEGURUAN DAN ILMU PENDIDIKAN

UNIVERSITAS LAMBUNG MANGKURAT

BANJARMASIN 


\section{KATA PENGANTAR}

Puji syukur atas kehadirat Allah SWT yang telah memberikan rahmat dan hidayah-nya sehingga kami dapat menyelesaikan tugas makalah yang berjudul .... ini tepat pada waktunya.

Adapun tujuan dari makalah ini adalah untuk memenuhi tugas dari Bapak Dr. Mohamad Zaenal Arifin Anis, M.Hum dan Bapak Mansyur, S.Pd., M.Hum. Pada mata kuliah Sejarah Eropa. Selain itu, makalah ini bertujuan untuk menambah wawasan tentang Negara Menurut Pemikiran Rousseau bagi para pembaca dan juga penulis.

Kami mengucapkan terimakasih kepada Bapak Dr. Mohamad Zaenal Arifin Anis, M.Hum dan Bapak Mansyur, S.Pd., M.Hum. selaku mata kuliah Sejarah Eropa yang telah memberikan tugas ini sehingga dapat menambah pengetahuan dan wawasan yang sesuai dengan bidang yang kami tekuni.

Banjarmasin, 10 Mei 2021

Kelompok 7 
JUDUL.......................................................................i

KATA PENGANTAR..........................................................ii

DAFTAR ISI............................................................iii

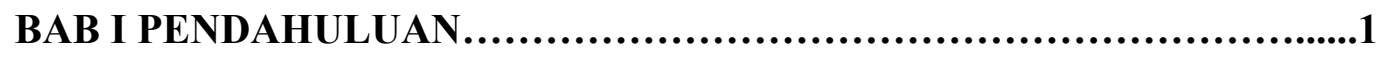

A. Latar Belakang Masalah..............................................

B. Rumusan Masalah....................................................... 1

C. Tujuan......................................................

BAB II PEMBAHASAN ......................................................2

A. Peranan Perempuan Dalam Suatu Kegiatan Wisata...................... 2

B. Meningkatkan Sumber Daya Manusia Dalam Bidang Kearsipan..........4

BAB III PENUTUP ...................................................6

A. Kesimpulan................................................6

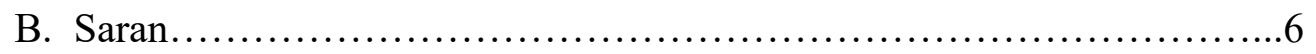

DAFTAR PUSTAKA...........................................................7 


\section{BAB I}

\section{PENDAHULUAN}

\section{A. Latar Belakang Masalah}

Perkembangan ekonomi menuju pada suatu pola pembagian kerja. Pola pembagian kerja tersebut dilakukan antara anggota keluarga. Kriteria pembagian kerja adalah kelompok umur dan jenis kelamin. Anak-anak mendapatkan pekerjaan yang lebih ringan, sementara beberapa kewajiban tertentu dikerjakan oleh perempuan dan kewajiban lainnya dilakukan oleh laki-laki. Masyarakat primitif maupun yang lebih maju menggangap bahwa pembagian kerja antara laki-laki dan perempuan merupakan suatu hal yang wajar (Sajogyo dan Sajogyo, 1984). Pemberdayaan perempuan dalam kegiatan wisata dapat dibedakan menjadi pemberdayaan psikologis, pemberdayaan sosial dan pemberdayaan politik. Pemberdayaan psikologis dapat dilihat dari rasa bangga masyarakat terhadap destinasi wisata ditempat tinggal mereka. Kedatangan wisatawan ditempat tinggal mereka untuk melihat keunikan budaya menjadi kebanggan bagi masyarakat yang ada disana. Perempuan dianggap sebagai agen pelestari budaya.

Arsip merupakan sebuah catatn atau rekaman yang diketik, dicetak ataupun ditulis dalam wujudu angka, gambar, dan huruf yang memiliki arti serta tujuan tertentu. Dengan adanya Globalisasi dan perdagangan bebas menjadikan fenomena yang menumbuhkan akumulasi persaingan yang kompetitif. Informasi yang dihasilkan akibat dari kegiatan/transaksi memiliki peranan yang penting untuk mencapai "Good Governance" (pemerintahan yang baik) dan "Good Corporate" (bisnis yang baik).

\section{B. Rumusan Masalah}

1. Bagaimana pemberdayaan perempuan dalam kegiatan wisata?

2. Bagaimana Meningkatkan Sumber Manusia Dalam Bidang Kearsipan?

\section{Tujuan}

1. Untuk mengetahui bagaimana pemberdayaan perempuan dalam kegiatan wisata.

2. Untuk mengetahui meningkatkan sumber manusia dalam bidang kearsipan. 


\section{BAB II \\ PEMBAHASAN}

\section{A. Peranan Perempuan Dalam Suatu Kegiatan Wisata}

Pengertian peran menurut soekanto (1990:268) menjelaskan bahwa peran adalah aspek dinamis dari kedudukan (status). Apabila seseorang melaksanakan hak dan kewajibannya sesuai dengan kedudukannya, maka dia menjalankan suatu peran. Peran berarti berbicara tentang harapan dan penantian orang lain terhadap perempuan Dengan kata lain, berbicara tentang apa yang dapat dilakukan perempuan dengan status dan kedudukannya sebagai perempuan. Adapun pengertian peran yang dikemukakan oleh Suratman adalah fungsi atau tingkah laku yang diharapkan ada pada individu seksual sebagai status aktifitas yang mencakup peran domestik maupun peran publik (dalam Wulansari:2011).

Pariwisata adalah salah satu industri model baru yang mampu menyediakan pertumbuhan ekonomi yang cepat dalam hal kesempatan kerja, pendapatan, taraf hidup dan dalam mengaktifkan sektor produksi lain di dalam negara penerima wisatawan. Disamping itu bahwa pariwisata dapat dipahami sebagai suatu sektor yang kompleks, meliputi industri- industri dalam arti yang klasik, seperti misalnya industri kerajinan tangan dan industri cinderamata. Penginapan dan transportasi secara ekonomi juga dipandang sebagai industri (Salah Wahab, 2003:5). Pariwisata menurut UU No. 10 Tahun 2009 Tentang Kepariwisataan yaitu berbagai macam kegiatan wisata dan didukung oleh berbagai fasilitas serta layanan yang disediakan masyarakat, pengusaha, pemerintah dan pemerintah daerah. Suatu destinasi dapat disebut sebagai destinasi wisata jika didalamnya tersedia komponen kepariwisataan (Sugiama, 2013).

Pemberdayaan perempuan dalam kegiatan wisata dapat dibedakan menjadi pemberdayaan psikologis, pemberdayaan sosial dan pemberdayaan politik. Pemberdayaan psikologis dapat dilihat dari rasa bangga masyarakat terhadap destinasi wisata ditempat tinggal mereka. Kedatangan wisatawan ditempat tinggal mereka untuk melihat keunikan budaya menjadi kebanggan bagi masyarakat yang ada disana. Perempuan dianggap sebagai agen pelestari budaya. Pemberdayaam sosial dapat terlihat dari kesempatan individu untuk terlibat dalam kegiatan wisata. Masyarakat biasanya bekerjasama untuk memenuhi kebutuhan wisatawan sehingga memunculkan kekompakan didalam masyarakat. Perempuan yang awalnya hanya dirumah tangga, dapat bekerja pada sektor wisata, menyediakan kebutuhan wisatawan. Kebersamaan 
dalam menyediakan kebutuhan kegiatan wisata dapat menimbulkan kebersamaan dan membentuk kelompok perempuan. Pemberdayaan politis ditandai dengan terbukanya kesempatan masyarakat dalam pengambilan keputusan terkait dengan kegiatan wisata. Perempuan mempunyai hak dalam hal pengambilan keputusan terkait dengan wisata, meskipun masih rendah peranan perempuan dalam pengambilan keputusan terkait dengan kegiatan wisata (Rahayu, 2018).

Perempuan mempunyai peranan yang sangat besar dalam kegiatan wisata. Perempuan menjadi lebih penting daripada laki-laki dalam kegiatan wisata karena tingginya kreativitas perempuan (Subekti, 2017). Keterlibatan perempuan dalam kegiatan wisata juga menguntungkan dalam kegiatan wisata baik secara kultural maupun secara sosial ekonomi. Keterlibatan perempuan dalam kegiatan wisata akan mewujudkan kesetaraan dan keadilan dalam kehidupan berkeluarga, pengembangan kemitraan yang harmonis dengan laki-laki, menciptakan kesetaraan gender dan meningkatkan peran dan kemandirian dari perempuan (Haryanto, 2017). Mengingat peran penting yang dimainkan perempuan dalam pariwisata, penting agar mereka juga terwakili dengan baik dalam kepemimpinan pariwisata. Kepemimpinan dalam pariwisata dapat memberdayakan dan menginspirasi wanita lain untuk menjadi lebih proaktif dalam mengejar peluang bisnis pariwisata.

Faktor budaya membatasi hak dan keterlibatan perempuan di tempat kerja. Agama masih memiliki peran kunci dalam menentukan norma-norma gender di banyak budaya dan pandangan fundamentalis lintas spektrum agama membatasi hak-hak wanita, termasuk hak yang terkait dengan seks dan seksualitas, dan untuk mobilitas dan pekerjaan. Sementara budaya politik penting untuk membawa perubahan, perempuan terus memiliki suara terbatas di tingkat lokal dan nasional, dan perempuan tidak dapat berpartisipasi sepenuhnya dalam sistem kekuasaan formal. Beberapa lokasi wisata di Indonesia, kegiatan wisata didominasi oleh perempuan. Kaum laki-laki menganggap sektor wisata bukan pekerjaan pokok tetapi merupakan pekerjaan sampingan. Perempuanlah yang mengelola kegiatan wisata, meskipun peranannya masih kurang optimal dan terbatas karena peran gandanya didalam keluarga (Subekti, 2017). Peranan perempuan dalam kegiatan wisata masih sangat terbatas. Kegiatan perempuan dalam kegiatan wisata adalah terbatas pada aktivitas membersihkan penginapan, tour guide, dan memasak. Perempuan hanya sebagai penjaga fasilitas pariwisata, bukan sebagai pelaku aktif dalam pariwisata (Sushartami, 2016; Subekti, 2017). Peranan dan partisipasi perempuan dalam kegiatan wisata juga 
masih dipandang belum penting (Haryanto, 2017). Pendapatan perempuan dalam kegiatan wisata terkadang juga tidak menentu dan tergolong rendah karena mayoritas penghasilan didapatkan dari pembagian hasil kegiatan. Banyak dari perempuan bekerja disektor pariwisata bukan dengan tujuan utama untuk mendapatkan penghasilan. Tujuan utamanya adalah untuk kegiatan sosial kemasyarakatan (Subekti, 2017).

Beberapa fakta umum tentang perempuan dalam pariwisata diuraikan oleh UNWTO (2011), sebagai berikut: a. Wanita memenuhi sebagian besar proporsi tenaga kerja pariwisata yang formal. b. Perempuan terwakili dalam pekerjaan pelayanan dan tingkat. administrasi, tetapi kurang terwakili pada tingkat profesional. c. Perempuan di bidang pariwisata biasanya mendapatkan $10 \%$ sampai $15 \%$ lebih sedikit dari pada tenaga kerja laki-laki. d. Sektor pariwisata manjadikan perempuan sebagai pemilik usaha/majikan yaitu hampir dua kali lipat jika dibandingkan dengan sektor lainnya. e. Satu dari lima menteri pariwisata di seluruh dunia adalah perempuan. f. Perempuan yang bekerja di sektor pariwisata menjadi pekerja sendiri/mandiri dengan proporsi yang jauh lebih tinggi dari pada sektor lain. g. Sejumlah besar pekerjaan tidak berbayar sedang dilakukan oleh perempuan dalam bisnis pariwisata keluarga.

Perempuan juga berisiko tereksploitasi dalam kegiatan wisata. Eksploitasi melalui pariwisata dapat mengambil berbagai bentuk: upah yang buruk, kondisi kerja yang berbahaya, diskriminasi seksual, pelecehan seksual, pelacuran, perbudakan, dan perdagangan manusia. Wanita dan anak-anak yang hidup dalam kemiskinan di negara-negara berkembang sangat rentan terhadap ancaman-ancaman ini. Pariwisata pekerja seks mungkin tampak memberikan jalan keluar dari kesulitan hidup sehari-hari, tetapi bisa berakibat jauh kesulitan jangka panjang yang lebih besar seperti HIV/AIDS dan penyakit menular seksual lainnya, dislokasi sosial, kemelaratan, atau kecanduan narkoba (UNWTO, 2011).

\section{B. Meningkatkan Sumber Daya Manusia Dalam Bidang Kearsipan}

Arsip merupakan sebuah catatn atau rekaman yang diketik, dicetak ataupun ditulis dalam wujudu angka, gambar, dan huruf yang memiliki arti serta tujuan tertentu. Arsip biasanya digunakan sebagai suatu bahan informasi dan juga komunikasi yang direkam dalam berbagai media. Kearsipan menurut UU No. 43 Tahun 2009 adalah hal - hal yang berkenaan dengan arsip. 
Dengan adanya Globalisasi dan perdagangan bebas menjadikan fenomena yang menumbuhkan akumulasi persaingan yang kompetitif. Informasi yang dihasilkan akibat dari kegiatan/transaksi memiliki peranan yang penting untuk mencapai "Good Governance" (pemerintahan yang baik) dan "Good Corporate" (bisnis yang baik). Karena itu pengelolaan informasi yang efektif dan efesien contohnya dengan menggunakan arsip akan memberikan nilai tambah untuk mendukung kegiatan dan mengantisipasi hilangnya dokumen yang mempunyai nillai memori organisasi dan memore kolektif bangsa. arsip tidak hanya dokumen biasa tetapi mengelolanya harus dituntut dari segi fisiknya dan juga haruus memehami dari segi struktur, konten dan konteksnya.

Menurut para ahli yaitu The liang Gie beliau menjelaskan bahwa arsip adalah kumpulan warkat yang disimpan secara terencana dan teratur karena memiliki niai suatu fungsi agar setiap kali dibutuhkan bisa ditemukan Kembali dengan cepat. Menurut Sularso Mulyoono arsip adalah penempatan berbagai kertas dalam suatu tempat penyimpanan yang baik menurut aturan yang sudah ditentukan terlebih dahulu dengan sedemikian rupa.

Seperti yang kita ketahui mengelola arsip tidak sembarangan terlebih lagi karena perkembangan Teknologi informasi yang begitu pesat sangat berpengaruh terhadap pengelolaan arsip dalam pengelolaannya arsup memiliki konsep, teori, dasar - dasar, dan peinsip - prinsip kearsipan yang menjadi pijakan.

Peran asosiasi profesi disini juga berpengaruh terhadap kearsipan yaitu menjembatani antara dunia Pendidikan dan dunia industry dalam memberikan rekomendasi keahlian dan sekaligus sebagai pengawasan kualitas lulusan. Bidang kearsipan membutuhkan prpfesional yang tidak hanya terkuat pada masalah teknis untuk dapat mengelola arsip tapi juga dapat mengikuti perkembangan jaman. Tetapi semua akan terlihat tidak tampak nyata jika pengakuan masyarakat terhadap bidang kearsipan masih rendah. Saat ini, penyediaan Pendidikan formal di bidang kearsipan masih kurang dan perkembangannya terkesan lambat (Bramantya \& Prasetyo, 2019; Hasanah, 2018; Sudiyanto, 2014). 


\section{BAB III}

\section{PENUTUP}

\section{A. Kesimpulan}

Keterlibatan perempuan dalam kegiatan wisata juga menguntungkan dalam kegiatan wisata baik secara kultural maupun secara sosial ekonomi. Keterlibatan perempuan dalam kegiatan wisata akan mewujudkan kesetaraan dan keadilan dalam kehidupan berkeluarga, pengembangan kemitraan yang harmonis dengan laki-laki, menciptakan kesetaraan gender dan meningkatkan peran dan kemandirian dari perempuan (Haryanto, 2017). Mengingat peran penting yang dimainkan perempuan dalam pariwisata, penting agar mereka juga terwakili dengan baik dalam kepemimpinan pariwisata.Pendapatan perempuan dalam kegiatan wisata terkadang juga tidak menentu dan tergolong rendah karena mayoritas penghasilan didapatkan dari pembagian hasil kegiatan.

Informasi yang dihasilkan akibat dari kegiatan/transaksi memiliki peranan yang penting untuk mencapai "Good Governance" (pemerintahan yang baik) dan "Good Corporate" (bisnis yang baik). Karena itu pengelolaan informasi yang efektif dan efesien contohnya dengan menggunakan arsip akan memberikan nilai tambah untuk mendukung kegiatan dan mengantisipasi hilangnya dokumen yang mempunyai nillai memori organisasi dan memore kolektif bangsa. Seperti yang kita ketahui mengelola arsip tidak sembarangan terlebih lagi karena perkembangan Teknologi informasi yang begitu pesat sangat berpengaruh terhadap pengelolaan arsip dalam pengelolaannya arsup memiliki konsep, teori, dasar - dasar, dan peinsip - prinsip kearsipan yang menjadi pijakan.

\section{B. Saran}

Kami menyadari bahwa masih banyak kekurangan dalam penulisan makalah ini. Oleh karena itu, kritik dan saran yang bersifat membangun selalu kami harapkan demi perbaikan dan kesempurnaan makalah kami. Dan semoga makalah ini dapat dijadikan sebagai sarana yang dapat mendorong Mahasiswa untuk bisa berfikir aktif dan kreatif. 


\section{DAFTAR PUSTAKA}

Arisanty, D. (2018). Pemberdayaan Perempuan Pada Kawasan Wisata: Studi Pada Pasar Terapung Lok Baintan.

Mukhlis, M. (2021). MENINGKATKAN SUMBER DAYA MANUSIA DALAM BIDANG KEARSIPAN. 